\title{
How Does Green Marketing Influence Consumers? The Market Trend Examination towards Environmentally Sustainable Products in Emerging Indian Cities
}

\author{
Balkrishan Sangvikar, Avinash Pawar, Ashutosh Kolte, Akshay Mainkar, Prasanna Sawant
}

\begin{abstract}
The environmental hazards being seen as concern all over the globe, the ill-effects of plastics, use-throw products, and environment affecting products have been observed as a problem of the world, and the process of finding the alternatives for this problem is in progress. The search has to direct us to reuse and recycle many products, and it has given rise to a new type of environmentally sustainable products. The products that cause less adverse effects on the surroundings and are made by the materials that are readily available and easily processed are the ones that are considered environmentally sustainable. Nowadays, these products are penetrating the markets and replacing the conventionally, readily available products. The awareness about the same is yet not well spread in India. A considerable class of population does not use these products and, unfortunately, are unaware of it. In India, the usage of long-lasting metal containers and reused fabrics are also considered as environmentally sustainable. Thus we are unknowingly using these products for years, but the percentage of use is very small. This paper is focused on awareness of these environmentally sustainable products, their use, and customer satisfaction. The questionnaire explores the customer's view on environmentally sustainable products, and analysis deliberates the factors such as rarity in the commercial market, customer satisfaction, high costs, and unawareness are some factors that kill the widespread of these products. In order to get clear insights and inferences, this study is purposefully done in new emerging smart cities of India where people are aware of these products.
\end{abstract}

Keywords : Sustainability in Business, Green Marketing, Environment-Friendly Products, Green Management, Eco-Marketing, Environmental Responsibility.

\section{INTRODUCTION}

In recent times, concepts like green marketing, sustainable marketing, eco-friendly marketing, or organic marketing are extensively used. It is reflecting the developing interest of customers and consumption based on the influence on environmental. Hoyer and MacInnis (2001) observed that the customers are more sensitive to their values and beliefs, and

Revised Manuscript Received on October 15, 2019.

* Correspondence Author

Balkrishan Sangvikar, Department of Management Sciences, Savitribai Phule Pune University, Pune, Maharashtra, India

Avinash Pawar, Department of Management Sciences, Savitribai Phule Pune University, Pune, Maharashtra, India

Ashutosh Kolte, Department of Management Sciences, Savitribai Phule Pune University, Pune, Maharashtra, India

Akshay Mainkar, Department of Management Sciences, Savitribai Phule Pune University, Pune, Maharashtra, India

Prasanna Sawant, Department of Management Sciences, Savitribai Phule Pune University, Pune, Maharashtra, India they need to be considered when evaluating and analysing its stimuli that affect their buying decisions. The customer values are lasting for a more prolonged period, and beliefs affect the behaviour, and this deserves to be included in consideration for the environment. Based on this aspect, green marketing is an opportunity to innovate the products and services in ways that make a difference and achieve business success without affecting the environment (Grant, 2007). The green marketing helps the consumers to recognize the prominence of environmental issues and their significant contribution to the sustainability efforts of the organisations. Hence, in order to apprehend the facts of green marketing in detail, it is essential to recognize the behaviour of green consumers. Although Elkington (1994) has defined a green consumer as a person involved in evading the usage of the products that threaten the natural environment due to their extensive use, production techniques, disposing processes, or involved in animal unkindness. It is further observed that from the 1990s that the consumers have started showing interest in green marketing and became more sensitive towards the environment (Strong, 1996). Furthermore, environmentally sustainable products primarily provide environmental, economic, and social benefits. It also includes the abstraction of raw materials, the use of products, and the final disposal while protecting the environment and public health over their whole life cycles. Since today is the state of constant development in terms of knowledge, technologies, and societal expectations, so sustainable products should undergo continuous improvement as far as social and environmental variations are considered.

The environment-friendly also called eco-friendly or nature-friendly, are the synonyms that are used to refer to the products related guidelines, policies, or laws that are considered to have the least impact on the environment. The products are marked with eco-labels to make consumers cognizant about the eco-friendly products. The customers purchase the products not only based on price, superiority, or needs but also on the social, ethical, and moral values that are associated with the product and organisation. This change in the preferences has witnessed a remarkable growth in the purchases of organic and environmentally sustainable products in the global market.

Peattie (2001) deliberated that the progression of green marketing has occurred majorly in three phases. The first phase was "Ecological" green marketing, which comprises of all marketing activities of the organisations that are concerned to protect the 
environment and provide effective resolutions for environmental problems during this period. The second phase was called as "Environmental" green marketing, the primary emphasis of this phase was implementing the clean technology emphasising on the design and development of the innovative products that take care of high priority global issues like pollution and waste management. The third phase was known as 'Sustainable' green marketing, which was evolved in early 2000 and focused on long term solutions for environmental problems through the involvement of all stakeholders. After this, there was a gradual development of green consumerism among the customers, which has directed to a more broadened ideology of consumption called as ethical consumerism (Uusitalo and Oksanen, 2004). The research conducted by Singh and Pandey (2012) elaborated that the Indian customers were started displaying a greater interest in green products. It was highlighted that consumers are responsive to the benefits of green products due to the efforts of green marketing. It is also deliberated that excellent communication about the cost, quality performance, and other characteristics of green products will direct to a noticeable growth in the consumption of green products.

The contribution of Polonsky (2011) discussed that the environmental marketing is generally recognised as green marketing and further defined the sustainable marketing as the exertion by an organisation to design, develop, promote, and distribute the products in a way that encourages the protection of the environment. Alston and Roberts (1999) executed an investigation on the green business approach and new product development process. They realised that the buyers are ready to accept these products and have the inclination to pay a little bit more for environmentally sustainable products. Furthermore, Armstrong and Kotler (2007) have defined environmental sustainability as a management approach that encompasses the development of business and product strategies that helps to sustain the environment and yields better revenues for the organisations. It is a challenging task for companies and crucial for the society and country. Hence, many organisations are now started captivating actions to safeguard, preserve, and save the environment. On a similar line, Porter (1998) has mentioned that in order to achieve sustainable competitive advantage, businesses must assimilate the environmental philosophy in all facets of their business processes and marketing functions.

\section{REVIEW OF LITERATURE}

The research of Lamb et al. (2004) has explicated that green marketing has developed as an essential approach for businesses to get a competitive advantage. The organisations conduct environment awareness programs and promote this prevalent issue, which helps to create loyalty of customers. The organisations are positioning themselves as environmentally and ecologically sustainable brands that convey the concern for the environment and society at large. Furthermore, Wong et al. (1996) elaborated that environmental issues are considered as the topmost social concerns. However, the growth of green products in the market has substantially dropped short of anticipations of marketers regarding green marketing. The intense growth and developments in green marketing initiatives at the start of the 1990s were started declining. While the organisational excitements for green marketing have slowly decreased (Peattie and Crane, 2005). Increasingly, marketers have realised that consumer thinking and their apprehension for the environmental aspirations for green products did not transform into their buying behaviour (Schrum et al., 1995). Furthermore, Hartmann \& Apaolaza-Ibáñez (2006) observed that endorsement of the ecofriendly products leads to consumer patronisation and in this process, it is ensured to contribute support for sustainability and environment towards the global issues by the customers. Ottoman (2006) described that green marketing must fulfill the essential purpose of improved environmental quality and satisfaction of customers. It was indicated that several green products have botched in the market due to the effect of green marketing myopia. The green marketing myopic signified that there is more emphasis on the greenness of the products over the broader expectations of consumers and other stakeholders.

A green consumer is elaborated by Peattie (2001) as somebody who willingly participates in customer practices that are considered as environment-friendly by the marketing academicians and professionals. Moreover, in the organisation context Driessen (2005) discovered that the optimal level of green efforts needs to be taken by the organisations regarding innovation, performance, and greenness to accomplish and endure a competitive advantage in the market. The market for environmentally sustainable products is becoming mainstream. Therefore, it is vital to identify the elements that impact the customer's decision making and product selection process in the marketplace. Based on research work, Tjärnemo (2001) deliberated that the organisational benefits of becoming more eco-oriented in approach and providing environment-friendly products result in improved market shares and image of the company, which aids the organisations in the achievement of better reputation, brand and competitiveness in the market. However, the study of Grob (1995) has elaborated on the changing behaviour of the customers in the context of the environmental impact, which has a direct influence on nature and the ecosystem. The green practices are acquiring impetus in businesses, which includes recycling products, saving paper and electricity, encouraging the usage of biodegradable products, and making a habit of using organic food (Gilg et al., 2005). It is also found in a survey made in New-Zealand that there is an effect of price consciousness, quality consciousness, environmental consciousness, and brand loyalty on customer behaviour (Gan et al., 2008).

In this context, Roger A Kerin et al. (2007) elaborated on the dimensions of green marketing in different forms. It consists of organisational opportunities for product development, consumer research, and pollution prevention programs for society. These dimensions also solicit employee suggestions to reduce pollution, recycle materials, and to develop new ways for a sustainable environment. Kollmuss and Agyeman (2002) developed a critical framework based on internal and external factors. The internal factors that promoted pro-environmental behaviour, which was found contradictory to customer's regular choices. It is mentioned that there is a non-availability of the decisive model which adequately explicates the gap between environmental understanding 
and pro-environmental behaviour. It was also found that environmentally conscious people do not necessarily behave pro-environmentally as per the situation or circumstances as they have a reactive progression in intended decision making (Ohtomo and Hirose, 2007). The consumer behaviour towards green marketing has various approaches, and they have been explained by examining the consumer attitude and evaluation towards their purchasing decisions for environmentally sustainable products (Solomon et al. 2010). It was iterated that the understanding and knowledge of customers about environmentally sustainable products have a significant impact on their decision-making process. Hence, these are the contributing elements that affect the customer purchase decisions of green products (Khare et al., 2013).

In a broader view, environmental sustainability marketing denotes the developing, building, and retaining environmentally sustainable associations with customers, society, and the natural environment (Charter and Polonsky, 1999). On the other side, Luck et al. (2009) have commented that the deterioration of the environment and careless attitude towards the environment has resulted in the improvement and implementation of new practices in business. The awareness and attitude of customers towards eco-friendly products or services aids in protecting the earth. So, Ramakishen et al. (2010) studied the factors assisting the organisations in adopting the green approach are organisational goodwill, differentiation of products, competition in the market, pressure groups, government regulations, consumer demand, and market threats.

Joseph \& Korlekar (2012) suggested that there is a broader scope and need to conduct detailed research on green marketing in emerging nations like India. This will help in understanding the customer's perception, their demographic profile, consumer attitude towards selecting the environment-friendly approach in their buying process, and factors for accepting green marketing and green products. Furthermore, Grant (2007) mentioned that the companies had realised their responsibility towards the environment and society in the current time. The organisations have embraced the "Go Green" approach in their businesses, and this has helped products and production processes become cleaner and greener. Now, corporations have realised that they can help in reducing pollution, save the environment, and still raise revenues at the same time (Hart, 1997). Green marketing is an ingenious and timely opportunity to innovate and help the environment and society in ways that make a difference, and at the same time, attain greater business accomplishments. On this line, the study executed by Bhattacharya (2011) elaborated that Indian green marketers must conduct more awareness programs and carry specific promotional campaigns to increase awareness. Most of the time, Indian customers are more concerned about the price, and they are not certain about the quality of green products. The majority of the Indian consumers are emotional buyers and do much emotional buying. Nowadays, many Indian consumers are aware and have a better orientation towards environmentally sustainable products. Hence there is a more significant scope for the expansion of the green market. Many companies in India have recognised this need of the customers and started the implementation of green marketing. Today, conscious consumers prefer products that are safe to consume and do not affect the environment. Hence, companies nowadays have adopted green marketing as an instrument for competitive advantage (Kang, A., 2015).

The literature review on the extent of green marketing has helped the researchers to recognize the need and scope for contribution in this domain in terms of analysing the perception of customers, the satisfaction of customers, their level of awareness and purchase goals towards the green marketing and products in the Indian business environment. This has further helped to design the hypothesis and questionnaire for the study.

\section{RESEARCH METHODOLOGY}

This study has a prime objective to understand the satisfaction of customers using environmentally sustainable products in order to determine market trends. While it also focuses on studying the consumer perception of spending on environmentally sustainable products. It also deliberates the various age groups and market trends in the context of environmentally sustainable products in India. The current study is based on the primary data collection through a questionnaire. The collected data is compiled and analyzed for the relations between various factors under consideration regarding the effect on environmentally sustainable products. Furthermore, the conclusions are derived based on the analysis of data.

This study shows how factors such as age, income group, the approach of consumers affect the use of environmentally sustainable products. This study also shows what point the individual consider before purchasing any environmentally sustainable products. The things may involve consumer's awareness, consumption, limitations to the use of such products, and their approach. The data is collected from the 227 respondents from Pune city of India using the Snowball Sampling method. While the data is evaluated using the statistical software of SPSS. The principal analysis is computed using the method Chi-Square test. The following approach was used to conduct this research.

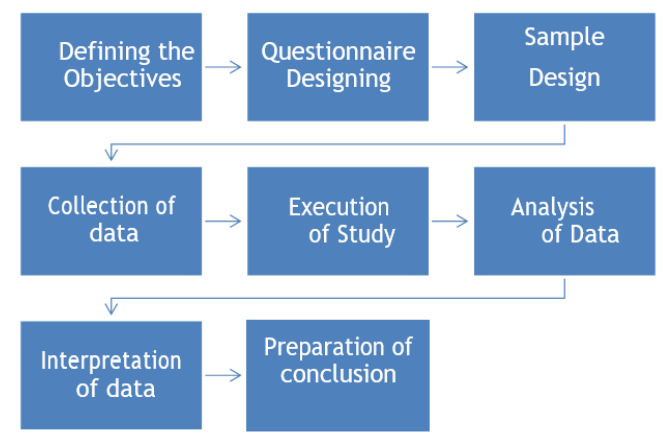

Figure 1: Adopted research approach

The above steps of conducting the research study were used to derive the inferences and reach to the outcome of this paper.

\section{ANALYSIS AND RESULTS}

This paper focuses on customer behaviour about environmentally sustainable products. It can be measured by the satisfaction that these 
products provide to the customers. They can determine product satisfaction, which in turn can determine their spending decisions about these products. If the spending increases, we can say that the product has a positive market trend that will increase the future consumption. Based on the review and synthesis of the literature, research objectives, and the interaction with the respondents, the hypothesises are derived (Table no 1). It is further analysed and tested with the variables. Consequently, this paper also differentiates the respondents on their age group and then looks for their attitude towards the environmentally sustainable products with their monthly spending and frequency of use.

A) Hypothesis Design:

In order to study and analyse the different dimensions related to customer orientation towards environmentally sustainable products, the following hypothesises are designed.

Table 1: Table of hypothesis

\begin{tabular}{|c|c|l|}
\hline No & Identifier & \multicolumn{1}{c|}{ Hypothesis } \\
\hline 1 & H1 & $\begin{array}{l}\text { There is a significant association } \\
\text { between respondent that considers } \\
\text { these products are economical with } \\
\text { customer satisfaction }\end{array}$ \\
\hline 2 & H2 & $\begin{array}{l}\text { There is a significant association } \\
\text { between the satisfaction of the } \\
\text { customer with changes brought in the } \\
\text { market }\end{array}$ \\
\hline 3 & H3 & $\begin{array}{l}\text { There is a significant association } \\
\text { between product usages of the } \\
\text { respondents with customer satisfaction }\end{array}$ \\
\hline 4 & H4 & $\begin{array}{l}\text { There is a significant association } \\
\text { between the incomes of the respondent } \\
\text { with satisfaction with the product }\end{array}$ \\
\hline 5 & H5 & $\begin{array}{l}\text { There is a significant association } \\
\text { between awareness about product and } \\
\text { customer satisfaction. }\end{array}$ \\
\hline
\end{tabular}

\begin{tabular}{|c|c|l|}
\hline 6 & H6 & $\begin{array}{l}\text { There is a significant association } \\
\text { between the age of the respondent with } \\
\text { the satisfaction of the product. }\end{array}$ \\
\hline 7 & H7 & $\begin{array}{l}\text { There is a significant association } \\
\text { between the availability of sustainable } \\
\text { products with customers spending on } \\
\text { these products. }\end{array}$ \\
\hline 8 & H8 & $\begin{array}{l}\text { There is a significant association } \\
\text { between acceptances of these products } \\
\text { with the spending on these products. }\end{array}$ \\
\hline 9 & H9 & $\begin{array}{l}\text { There is a significant association } \\
\text { between if the customer finds these } \\
\text { products economical and their } \\
\text { frequency of using it. }\end{array}$ \\
\hline 10 & H10 & $\begin{array}{l}\text { There is a significant association } \\
\text { between if the customer likes this } \\
\text { change and their spending on these } \\
\text { products. }\end{array}$ \\
\hline
\end{tabular}

The statistical methods and tests are used for examination of the collected data, analysis of data, and forecasting findings for the research work. The statistical software package of SPSS is used by the researcher for interactive or batched statistical analysis. It is the short form for Statistical Package for the Social Sciences, which reveals its original use of analytical tools in the field of social sciences. Its usage has also extended into other data analysis types and systems. A test of chi-square statistics is used to examine whether distributions of categorical variables produce data in numerical form. The method of the chi-square test is used for our analysis, which emphasises the testing of two categorical variables is related to the population.

B) Hypothesis Analysis:

Hypothesis 1 (H1): There is a significant association between respondent that considers these products are economical with customer satisfaction

Table 2: Chi-square statistics and cross-tabulation for hypothesis (H1) of products are economical with customer satisfaction

\begin{tabular}{|l|c|c|c|}
\hline \multicolumn{1}{|c|}{ Chi-Square Statistics } & Value & Df & $\begin{array}{c}\text { Asymptotic Significance } \\
\text { (2- sided) }\end{array}$ \\
\hline Chi-Square (Pearson) & $23.728^{\mathrm{a}}$ & 4 & 0 \\
\hline Likelihood Ratio & 24.868 & 4 & 0 \\
\hline Linear Association & 20.366 & 1 & 0 \\
\hline Valid Cases & 227 & & \\
\hline
\end{tabular}

a. 2 cells $(20.0 \%)$ have expected count less than 5 . The minimum expected count is 0.45 .

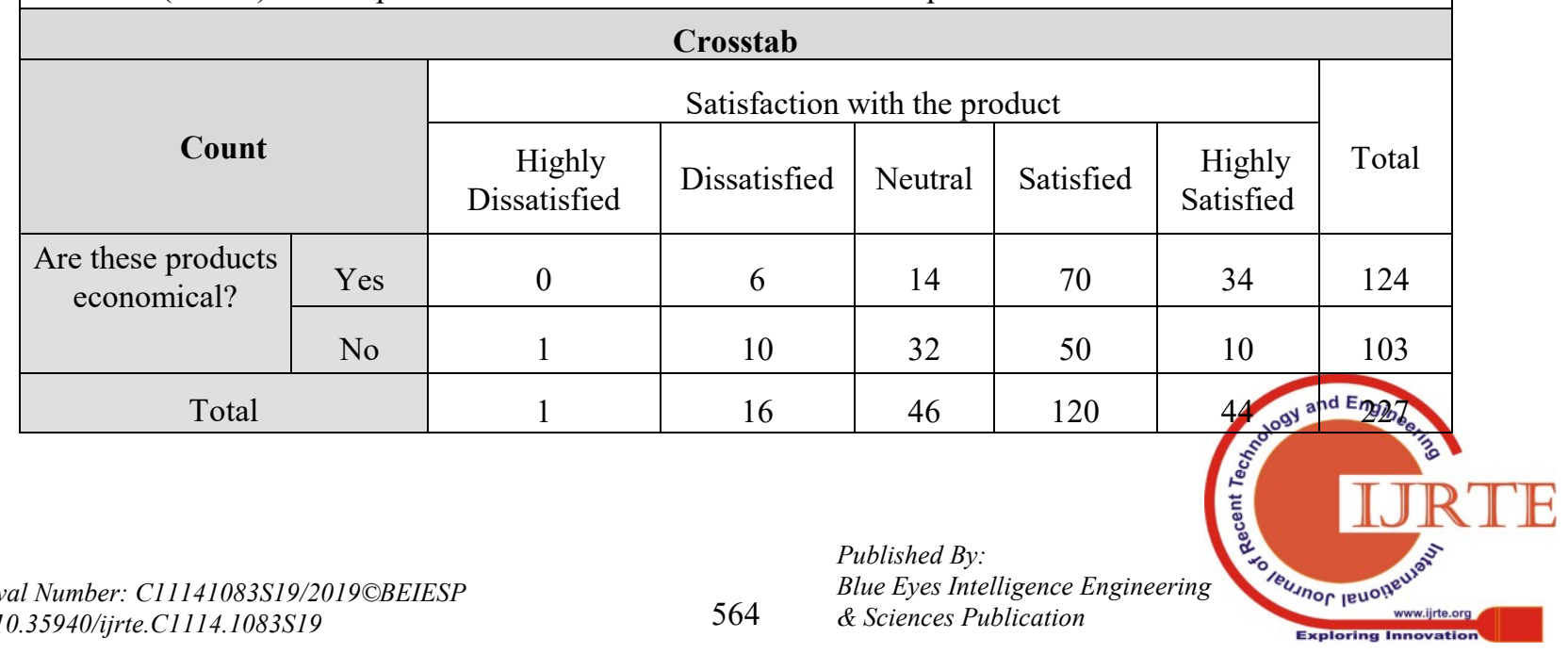


For the hypothesis variables, the chi-square coefficient computed is 0.00 , which indicates $100 \%$ confidence levels for the association of variables and indicates a significant relationship between a product being economical and customer satisfaction and proving that our hypothesis $\mathrm{H} 1$ is valid and reliable. From the cross-tabulation, we can say that people that consider the products are economical. They are highly satisfied with environmentally sustainable products.
On the other hand, people that are not satisfied with the economically sustainable product consider it as it is not economical.

Hypothesis 2 (H2): There is a significant association between the satisfaction of the customer with changes brought in the market

Table 3: Chi-square statistics and cross-tabulation for hypothesis (H2) of satisfaction of the customer with changes brought in the market

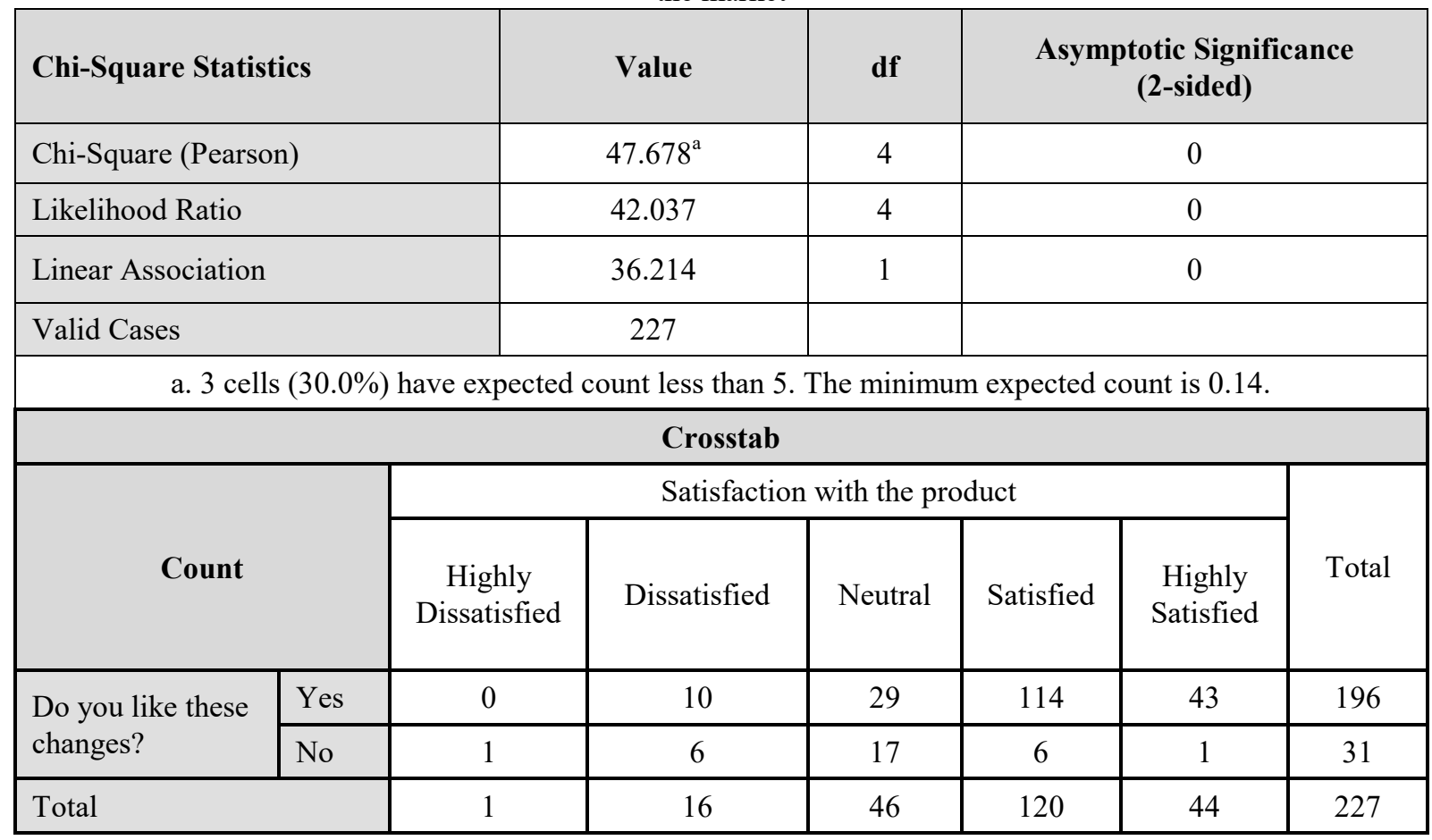

For the hypothesis variables, the chi-square coefficient computed is 0.00 , which indicates $100 \%$ confidence levels for the association of variables and indicates a significant relationship between satisfaction of the customer and changes brought in the market in sustainable product and proving that our hypothesis $\mathrm{H} 2$ is valid and reliable. From the Cross tabulation, we can see that most of the peoples around $86.34 \%$ like the changes brought in the market in the sustainable product, while $58.14 \%$ of customers who liked the changes were satisfied with these products.

Hypothesis 3 (H3): There is a significant association between product usage of the respondent with customer satisfaction

Table 4: Chi-square statistics and cross-tabulation for hypothesis (H3) of a product usage of the respondent with Customer Satisfaction.

\begin{tabular}{|l|c|c|c|}
\hline \multicolumn{1}{|c|}{ Chi-Square Statistics } & Value & df & $\begin{array}{c}\text { Asymptotic Significance } \\
\text { (2-sided) }\end{array}$ \\
\hline Chi-Square (Pearson) & $175.553^{\mathrm{a}}$ & 12 & 0 \\
\hline Likelihood Ratio & 64.7 & 12 & 0 \\
\hline Linear Association & 33.461 & 1 & 0 \\
\hline Valid Cases & 227 & & 0.01 \\
\hline \multicolumn{2}{|c|}{ Crosstab } \\
\hline \multicolumn{2}{|c|}{} \\
\hline
\end{tabular}


How Does Green Marketing Influence Consumers? The Market Trend Examination towards Environmentally Sustainable Products in Emerging Indian Cities

\begin{tabular}{|l|l|c|c|c|c|c|c|}
\hline \multicolumn{2}{|c|}{ Count } & \multicolumn{5}{c|}{ Satisfaction with the product } \\
\cline { 3 - 8 } & $\begin{array}{c}\text { Highly } \\
\text { Dissatisfied }\end{array}$ & Dissatisfied & Neutral & Satisfied & $\begin{array}{c}\text { Highly } \\
\text { Satisfied }\end{array}$ & $\begin{array}{c}\text { Tota } \\
1\end{array}$ \\
\hline \multirow{3}{*}{$\begin{array}{l}\text { How often do you use } \\
\text { the product? }\end{array}$} & Daily & 0 & 3 & 12 & 25 & 28 & 68 \\
\cline { 2 - 8 } & Once in a week & 0 & 3 & 21 & 81 & 13 & 118 \\
\cline { 2 - 8 } & Once in a month & 0 & 10 & 12 & 14 & 3 & 39 \\
\cline { 2 - 9 } & Never & 1 & 0 & 1 & 0 & 0 & 2 \\
\hline
\end{tabular}

For the hypothesis variables, the chi-square coefficient computed is 0.00 , which signifies that there is a complete positive association between usage of the product and the satisfaction of the customer. This validates the H3 hypothesis. Cross tabulation shows that respondents using products at least once a week are highly satisfied with the products. We can say that the use of the product also determines the satisfaction of the customer. Around $30 \%$ of the respondents are frequent users and are satisfied with the product.

Hypothesis 4 (H4): There is a significant association between the income of the respondent with satisfaction with the product

Table 5: Chi-Square Statistics for hypothesis (H4) of income and satisfaction with the product

\begin{tabular}{|l|c|c|c|}
\hline \multicolumn{1}{|c|}{ Chi-Square Statistics } & Value & df & $\begin{array}{c}\text { Asymptotic Significance } \\
\text { (2- sided) }\end{array}$ \\
\hline Chi-Square (Pearson) & $8.506^{\mathrm{a}}$ & 12 & 0.744 \\
\hline Likelihood Ratio & 10.109 & 12 & 0.606 \\
\hline Linear Association & 3.74 & 1 & 0.053 \\
\hline Valid Cases & 227 & & \\
\hline
\end{tabular}

a. 10 cells $(50.0 \%)$ have expected count less than 5 . The minimum expected count is 0.03 .

For the hypothesis variables, the chi-square coefficient computed is 0.744 , which indicates $25.6 \%$ confidence levels for the association of variables and indicates there is no significant relationship between income of the respondent and satisfaction with the product and proving that our hypothesis $\mathrm{H} 4$ is invalid. Hence there is no significant relationship between the income of the respondent with satisfaction with the product; hence, we cannot assume any relationships from the studied sample.

Hypothesis 5 (H5): There is a significant association between awareness about the product and customer satisfaction

Table 6: Chi-square statistics and cross-tabulation for hypothesis (H5) of awareness about the product and customer satisfaction

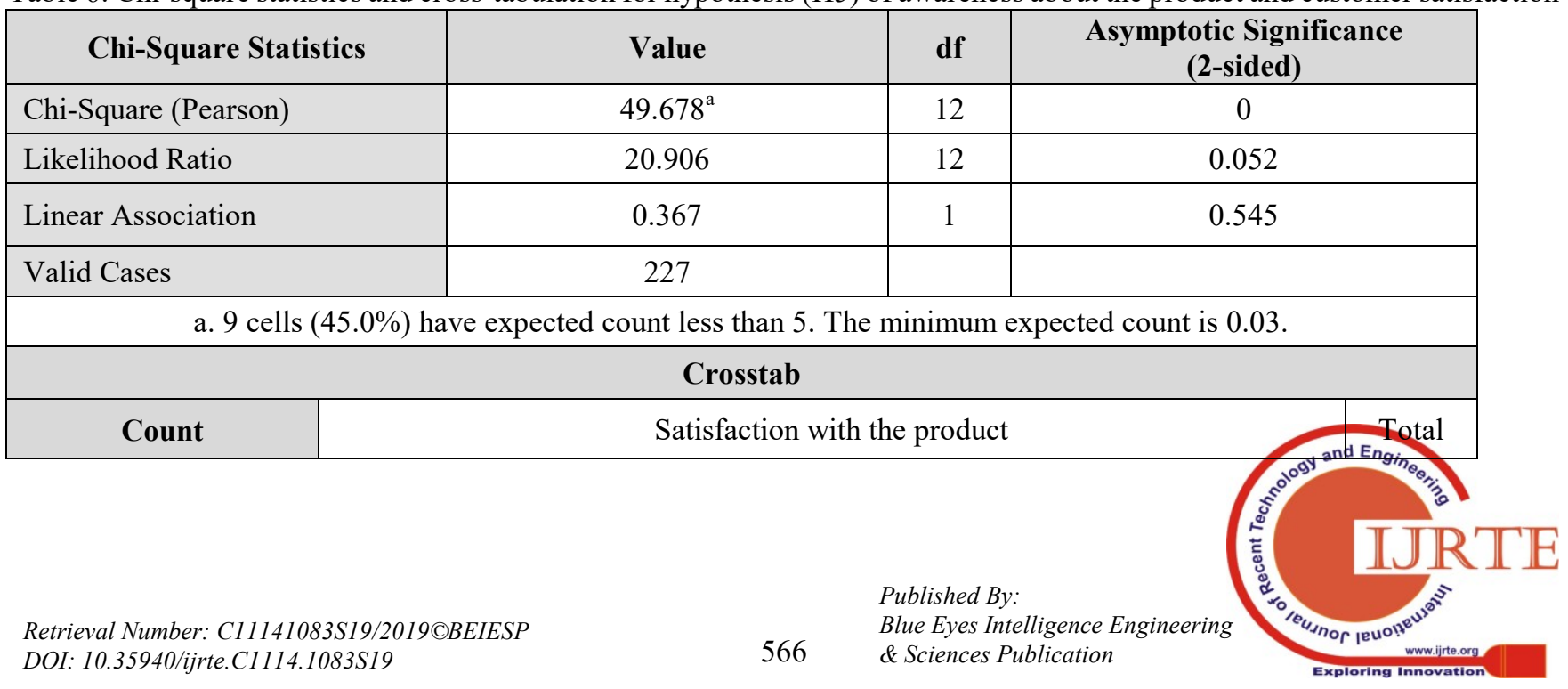




\begin{tabular}{|c|c|c|c|c|c|c|c|}
\hline & Range & $\begin{array}{c}\text { Highly } \\
\text { Dissatisfied }\end{array}$ & Dissatisfied & Neutral & Satisfied & $\begin{array}{l}\text { Highly } \\
\text { Satisfied }\end{array}$ & \\
\hline \multirow{4}{*}{$\begin{array}{l}\text { How often in a month } \\
\text { do you come across } \\
\text { Restaurants using } \\
\text { paper straws \& } \\
\text { recyclable coffee } \\
\text { cups? }\end{array}$} & 01-10 & 0 & 4 & 11 & 33 & 9 & 57 \\
\hline & $11-20$ & 0 & 3 & 19 & 48 & 14 & 84 \\
\hline & $21-30$ & 0 & 9 & 13 & 37 & 21 & 80 \\
\hline & Never & 1 & 0 & 3 & 2 & 0 & 6 \\
\hline \multicolumn{2}{|l|}{ Total } & 1 & 16 & 46 & 120 & 44 & 227 \\
\hline
\end{tabular}

For the hypothesis variables, the chi-square coefficient computed is 0.00 , which indicates $100 \%$ confidence levels for the association of variables and indicates a significant relationship between awareness about the product and customer satisfaction, proving that our hypothesis $\mathrm{H} 5$ is valid and reliable. From the responses received, we can observe that $72 \%$ of respondents that are satisfied with products visit the restaurants using these products more frequently. This can be said that the people that come across these products due to external reasons are still satisfied with the products. Thus these products can have a better future to be used in such places.

Hypothesis 6 (H6): There is a significant association between the age of the respondent with the satisfaction of the product

Table 7: Chi-Square Statistics for hypothesis (H6) of age and satisfaction of the product

\begin{tabular}{|l|c|c|c|}
\hline Chi-Square Statistics & Value & df & Asymptotic Significance (2-sided) \\
\hline Chi-Square (Pearson) & $6.734^{\mathrm{a}}$ & 12 & 0.875 \\
\hline Likelihood Ratio & 8.416 & 12 & 0.752 \\
\hline Linear Association & 0 & 1 & 0.994 \\
\hline Valid Cases & 227 & & \\
\hline \multicolumn{2}{|c|}{ a. 10 cells (41.7\%) have expected count less than 5. The minimum expected count is 0.67. }
\end{tabular}

For the hypothesis variables, the chi-square coefficient computed is 0.875 , which indicates $12.5 \%$ confidence levels for the association of variables and indicates no significant relationship between the age group of respondents and satisfaction of product and proving that our hypothesis H6 is invalid and not reliable. Hence there is no significant relationship between the age of respondents and satisfaction of product, and hence, researchers cannot assume any relationships from the studied sample. From the cross-tabulation, we can say that there is no significant correlation between the income of the respondent and satisfaction with the product.

Hypothesis 7 (H7): There is a significant association between the availability of product and customer spending on these products

Table 8: Chi-square statistics and cross-tabulation for hypothesis (H7) of the availability of product and customer spending

\begin{tabular}{|c|c|c|c|}
\hline Chi-Square Statistics & Value & df & Asymptotic Significance (2-sided) \\
\hline Chi-Square (Pearson) & $10.410^{\mathrm{a}}$ & 3 & 0.015 \\
\hline Likelihood Ratio & 10.998 & 3 & 0.012 \\
\hline Linear Association & 9.591 & 1 & 0.002 \\
\hline Valid Cases & 227 & & \\
\hline \multicolumn{4}{|c|}{ a. 0 cells $(0.0 \%)$ have expected count less than 5 . The minimum expected count is 8.04 . } \\
\hline \multicolumn{4}{|c|}{ Crosstab } \\
\hline Count & \multicolumn{3}{|c|}{$\begin{array}{l}\text { Spending on these products in a month and availability of the } \\
\text { product }\end{array}$} \\
\hline
\end{tabular}


How Does Green Marketing Influence Consumers? The Market Trend Examination towards Environmentally Sustainable Products in Emerging Indian Cities

\begin{tabular}{|l|l|c|c|c|}
\cline { 3 - 4 } \multicolumn{2}{c|}{} & \multicolumn{2}{|c|}{ Availability of product } & \multirow{2}{*}{ Total } \\
\cline { 3 - 4 } \multicolumn{2}{c|}{} & Yes & No & \\
\hline \multirow{3}{*}{$\begin{array}{l}\text { Spending on } \\
\text { these products } \\
\text { in a month }\end{array}$} & $0-100$ & 30 & 26 & 56 \\
\cline { 2 - 4 } & $101-500$ & 44 & 21 & 65 \\
\cline { 2 - 4 } & $501-1000$ & 58 & 23 & 81 \\
\cline { 2 - 4 } & More than 1000 & 22 & 3 & 25 \\
\hline \multicolumn{2}{|c|}{ Total } & 154 & 73 & 227 \\
\hline
\end{tabular}

For the hypothesis variables, the chi-square coefficient computed is 0.015 , which indicates $98.5 \%$ confidence levels for the association of variables and indicates a significant relationship between the availability of product and customers spending on these products and proving that our hypothesis $\mathrm{H} 7$ is valid and reliable. From the cross-tabulation, we can see that most of the customers, i.e., around $67.84 \%$ of respondents find these products are readily available in the market, and around $53.30 \%$ of the customers spend up to Rs 500 per month on these products.

Hypothesis 8 (H8): There is a significant association between the acceptance of these products with the spending on these products

Table 9: Chi-square statistics and cross-tabulation for hypothesis (H8) of liking the change and customer spending

\begin{tabular}{|c|c|c|c|c|c|c|}
\hline \multicolumn{2}{|c|}{ Chi-Square Statistics } & \multicolumn{2}{|c|}{ Value } & df & \multicolumn{2}{|c|}{$\begin{array}{c}\text { Asymptotic Significance (2- } \\
\text { sided) }\end{array}$} \\
\hline \multicolumn{2}{|c|}{ Chi-Square (Pearson) } & \multicolumn{2}{|c|}{$5.042^{\mathrm{a}}$} & 3 & \multicolumn{2}{|c|}{0.169} \\
\hline \multicolumn{2}{|l|}{ Likelihood Ratio } & \multicolumn{2}{|c|}{5.467} & 3 & \multicolumn{2}{|c|}{0.141} \\
\hline \multicolumn{2}{|l|}{ Linear Association } & \multicolumn{2}{|c|}{0.123} & 1 & \multicolumn{2}{|c|}{0.726} \\
\hline \multicolumn{2}{|l|}{ Valid Cases } & \multicolumn{2}{|c|}{227} & & & \\
\hline \multicolumn{7}{|c|}{ a. 1 cells $(12.5 \%)$ have expected count less than 5 . The minimum expected count is 3.41 . } \\
\hline \multicolumn{7}{|c|}{ Crosstab } \\
\hline \multirow{2}{*}{\multicolumn{2}{|c|}{ Count }} & \multicolumn{4}{|c|}{ Spending on this product in a month } & \multirow{2}{*}{ Total } \\
\hline & & $0-100$ & $101-500$ & $501-1000$ & More than 1000 & \\
\hline \multirow{2}{*}{$\begin{array}{l}\text { Do you like these } \\
\text { changes? }\end{array}$} & Yes & 50 & 57 & 65 & 24 & 196 \\
\hline & No & 6 & 8 & 16 & 1 & 31 \\
\hline \multicolumn{2}{|c|}{ Total } & 56 & 65 & 81 & 25 & 227 \\
\hline
\end{tabular}

For the hypothesis variables, the chi-square coefficient computed is 0.169 , which indicates $83.1 \%$ confidence levels for the association of variables and indicates a significant relationship between acceptance of these products with the spending on these products proving that our hypothesis $\mathrm{H} 8$ is invalid and not reliable. Hence there no significant association between the acceptance of these products with the spending on these products. From the Cross tabulation, we can say that there is no significant correlation between Income of the respondent and satisfaction with the product.

Hypothesis 9 (H9): There is a significant association between if the customer finds these products economical and their frequency of using it.

Table 10: Chi-square statistics and cross-tabulation for hypothesis (H9) of the economy of products and the frequency of use

\begin{tabular}{|l|c|c|c|}
\hline \multicolumn{1}{|c|}{$\begin{array}{c}\text { Chi-Square Statistics } \\
\text { Chi-Square (Pearson) }\end{array}$} & Value & df & $\begin{array}{c}\text { Asymptotic Significance } \\
\text { (2-sided) }\end{array}$ \\
ieval Number: C11141083S19/2019 $\mathrm{CBEIESP}$ & $9.317^{\mathrm{a}}$ & 3 & $\begin{array}{l}\text { Published By: } \\
\text { Blue Eyes Intelligence Engineering } \\
\text { \& Sciences Publication }\end{array}$
\end{tabular}




\begin{tabular}{|l|c|c|c|}
\hline Likelihood Ratio & 10.116 & 3 & 0.018 \\
\hline Linear Association & 8.425 & 1 & 0.004 \\
\hline Valid Cases & 227 & & \\
\hline
\end{tabular}

a. 2 cells $(25.0 \%)$ have expected count less than 5 . The minimum expected count is 0.91 .

\begin{tabular}{|l|l|c|c|c|}
\hline \multicolumn{2}{|c|}{ Count } & \multicolumn{2}{c|}{ Are these products economical? } & \multirow{2}{*}{ Total } \\
\cline { 3 - 5 } & & Yes & No & \\
\hline \multirow{4}{*}{$\begin{array}{l}\text { How often do you } \\
\text { use the product? }\end{array}$} & Daily & 44 & 24 & 68 \\
\cline { 2 - 5 } & Once in a week & 65 & 53 & 118 \\
\cline { 2 - 5 } & Once in a Month & 15 & 24 & 22 \\
\cline { 2 - 5 } & Never & 0 & 103 & 227 \\
\hline
\end{tabular}

For the hypothesis variables, the chi-square coefficient computed is 0.025 , which indicates $97.5 \%$ confidence levels for the association of variables and indicates a significant relationship between if the customer finds these products economical and their frequency of using it and proving that our hypothesis $\mathrm{H} 9$ is valid and reliable. From the cross-tabulation, we can see that most of the customers, i.e., around $54.62 \%$ finds these products economical, and around
$81.93 \%$ of the customers use these products more frequently, i.e., $51.98 \%$ use it once in a week, and $29.95 \%$ of customers use it daily.

Hypothesis 10 (H10): There is a significant association between if the customer likes this change and their spending on these products

Table 11: Chi-square statistics and cross-tabulation for hypothesis (H10) of customer liking and spending on the products

\begin{tabular}{|l|c|c|c|}
\hline \multicolumn{1}{|c|}{ Chi-Square Statistics } & Value & Df & $\begin{array}{c}\text { Asymptotic Significance } \\
\text { (2-sided) }\end{array}$ \\
\hline Chi-Square (Pearson) & $5.042 \mathrm{a}$ & 3 & 0.169 \\
\hline Likelihood Ratio & 5.467 & 3 & 0.141 \\
\hline Linear Association & 0.123 & 1 & 0.726 \\
\hline Valid Cases & 227 & & \\
\hline
\end{tabular}

a. 1 cells $(12.5 \%)$ have expected count less than 5 . The minimum expected count is 3.41 .

\begin{tabular}{|c|c|c|c|c|c|c|}
\hline \multicolumn{7}{|c|}{ Crosstab } \\
\hline \multirow{2}{*}{\multicolumn{2}{|c|}{ Count }} & \multicolumn{4}{|c|}{ Spending on these products in a month } & \multirow{2}{*}{ Total } \\
\hline & & $0-100$ & $101-500$ & $501-1000$ & More than 1000 & \\
\hline \multirow{2}{*}{$\begin{array}{l}\text { Do you like these } \\
\text { changes? }\end{array}$} & Yes & 50 & 57 & 65 & 24 & 196 \\
\hline & No & 6 & 8 & 16 & 1 & 31 \\
\hline \multicolumn{2}{|c|}{ Total } & 56 & 65 & 81 & 25 & 227 \\
\hline
\end{tabular}

For the hypothesis variables, the chi-square coefficient computed is 0.169 , which indicates $83.1 \%$ confidence levels for the association of variables and indicates a significant relationship between customers liking of these changes and their spending on it and proving that our hypothesis H10 is invalid and not reliable. Hence, there is no significant association between if the customer likes this change and their spending on these products. From the cross-tabulation, we can say that there is no significant correlation between the income of the respondent and satisfaction with the product. 


\section{FINDINGS OF STUDY}

Based on the analysis of data and testing of the hypothesis, the researchers have confirmed that green marketing has encouraging implications in the Indian business environment. It is found that there is a positive association between considering that green products are economical with customer satisfaction. Today the customer is also satisfied with the changes brought in the market due to the adaptation of the green approaches by organisations. The customers have awareness about green products, especially in urban cities. They have started using these products and have considerable satisfaction. The customers are also aware of the details of the green products, which have a positive association with their satisfaction level. Many new green products have started entering the market, and the availability of these products also affects the satisfaction of the customers. The pricing and economy of green products play an essential role in consumer buying decisions. The consumers are satisfied if the products fit in their economic range. While the income and age of the customer do not affect their satisfaction levels as well as the acceptance of products and likings of change related to green products is not influenced by the spending of the customers on green products.

\section{CONCLUSION}

This research highlights the marketing opportunities for environmentally sustainable products and consumer behaviour in a smart city. It provides consumer perspectives and their approaches to purchasing environmentally sustainable products. The outcome of this study also reflects that the industries have a high concern for environmental protection, and green marketing can be considered as a tool for gaining competitive advantage and sustainable growth in the Indian marketplace. The approach towards environmentally sustainable products is highly favorable in emerging smart cities in India. The frequent use of these products shows excellent customer satisfaction, and thus, the market trend is highly positive. The future of these products shows a promising market opportunity. The availability of these products determines customer expenditure on the same. Therefore, we can say that the customer base is available for environmentally sustainable products. Importantly, the age group does not perform a substantial role in the usage of these green products. The sustainability of the environment and the use of eco-friendly products is the responsibility of the government, producers as well as consumers. The behaviour of consumers is dynamic, and hence, they may use environmentally sustainable products in their day to day life as per their preference, perceptions, and satisfaction towards the environment-friendly products. Hence, it is a greater challenge for the producers and the government to address the problems and issues for integrating the green approach in business and fulfill the needs of the customers. This paper helps to realise customer behaviour towards environmentally sustainable products in India.

\section{REFERENCES}

1. Alston, K., \& Roberts, P. (1999). Partners in new product development: $\mathrm{SC}$ Johnson and the alliance for environmental innovation. Corporate Environmental Strategy, 6(2), 110-28.

2. Armstrong, G., \& Kotler, P. (2007). Marketing: An Introduction, 8th Edition, Pearson Prentice Hall, USA

3. Bhattacharya, S. (2011). Consumer Attitude towards Green Marketing in India”, The IUP Journal of Marketing Management, Vol. 10, No. 4, pp. $62-70$.

4. Lamb, C., Hair, J., and McDaniel, C. (2004). Marketing, 7th Edition, Thomson Asia(P) Ltd, Singapore, pp. 517 - 518.

5. Charter M, Polonsky M. (1999). Greener Marketing: a Global Perspective on Greening Marketing Practice, 2nd edition, Greenleaf: Sheffield.

6. Driessen, P. (2005). Green product innovation strategy. Tilburg: CentER, Center for Economic Research.

7. Elkington, J. (1994). Towards the sustainable corporation: Win-win-win business strategies for sustainable development. California Management Review, 36(2), pp. 90-100.

8. Gan, C., Wee, H., Ozanne, L., \& Kao., T. (2008). Consumer's purchasing behavior towards green products in New Zealand. Innovative Marketing, Vol. 4(1), pp. 93-102.

9. Gilg, A., Barr, S., and Ford, N. (2005). Green consumption or sustainable lifestyles? Identifying the sustainable consumer', Futures, 37(6), pp. 481-504

10. Grant, J. (2007). The Green Marketing manifesto. Padstow: John Wiley $\&$ Sons, Ltd

11. Grob, A. (1995). A structural model of environmental attitudes and behavior. Journal of Environmental Psychology, 15(3), pp. 209-220.

12. Hart, S. (1997). Beyond Greening: Strategies for a Sustainable World. Harvard Business Review, pp. 67-76. Retrieved from http://www.stuartlhart.com/ sites/stuartlhart.com/files/Beyond\%20Greening\%20 PDF_0.pdf.

13. Hartmann, P., and Apaolaza-Ibanez., V. (2009). Green Advertising revisited. International Journal of Advertising. Vol .28 No 4 , pp.715-739.

14. Hoyer, W., \& MacInnis, D. (2001). Consumer Behavior. 2nd ed., Boston, Houghton Mifflin Company.

15. Joseph \& Korlekar, R. (2012). Green Marketing Practices - An Indian Perspective. Expressions - Unity CSR Foundation Magazine, 2(2), pp. 12-15.

16. Kang, A. (2015). Brand love-moving beyond loyalty an empirical investigation of perceived brand love of Indian consumer. Arab Economic and Business Journal, 10(2), 90-101.

17. Kerin, Roger A., Hartley, Steven, Berkowitz, Eric N., and Rudelius, William (2007), Marketing, Tata McGraw-Hill Publishing Company Limited, New Delhi, pp. 108

18. Khare, A., Mukerjee, S. and Goyal, T. (2013) 'Social influence and green marketing: An exploratory study on Indian consumers', Journal of Customer Behaviour, 12(4), pp. 361-381.

19. Kollmuss, A. and Agyeman, J., 2002. Mind the Gap: why do people act environmentally and what are the barriers to pro-environmental behavior? Environmental Education Research, Vol. 8, (3), pp 239-260.

20. Luck, M., \& Ginanti, A. (2009). Mapping Consumer's attitudes for future sustainable. Marketing Australian and New Zealand Marketing Academic. AANZMAC 2009. pp. 1-8.

21. Mishra, P. and Sharma, P. (2010). Green Marketing in India: Emerging Opportunities and Challenges. Journal of Engineering, Science \& Management Education, 3, pp. 9-14.

22. Ottman, J. A., Stafford, E. R., \& Hartman, C. L. (2006). Avoiding green marketing myopia: Ways to improve consumer appeal for environmentally preferable products. Environment: Science and Policy for Sustainable Development, 48(5), 22-36.

23. Peattie, K. and Ratnayaka, M. (1992), Responding to the Green Movement, Journal of Industrial Management, 21(2): 103-110.

24. Paettie, K., \& Crane, A. (2005). Green marketing: legend, myth, farce or prophecy. Qualitative Market Research: An International Journal, 8(4), 357-370.

25. Polonsky, M. J. (2011). Transformative green marketing: Impediments and opportunities. Journal of Business Research, 64(12), 1311-1319.

26. Porter, M.E. (1998). Competitive Advantage. Creating and Sustaining Superior Performance; Free Press: New York, NY, USA, 1998; p. 221, ISBN 0-684-841-46.

27. Ramakishen, Goradia, Chirag and Shah, J. (2010). Green Marketing: The Future of Marketing. Marketing Conference, Vol. 1, No. 2, pp. 55-61.

28. Schrum, L., McCarty, J. and Lowrey, T. (1995). Buyer Characteristics of the Green

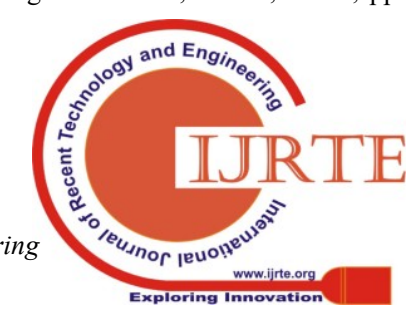


Consumer and their Implications for Advertising Strategy. Journal of Advertising 24(2): 71-82.

29. Singh, P.B. and Pandey (2012). Green Marketing: policies and practices for sustainable development', Integral Review -A Journal of Management, 5(1).

30. Solomon, M. R., G. Bamossy, S. Askegaard, and M. K. Hogg (2010). Consumer Behaviour: A European Perspective. 4th edition. New York: Prentice Hall.

31. Strong, C. (1996). Features contributing to the growth of ethical consumerism: a preliminary investigation. Marketing Intelligence \& Planning, 14 (5), 5-13.

32. Tjärnemo, H. (2001). Eco-marketing \& Eco-management - Exploring the eco-orientation - performance link in food retailing. Lund Business Press, Institute of Economic Research, Sweden

33. Uusitalo, O. and Oksanen, R. (2004). Ethical consumerism: a view from Finland. International Journal of Consumer studies, Vol. 28 No. 3, pp. 214-21.

34. Wong, V., Turner, W., \& Stoneman, P. (1996). Marketing strategies and market prospects for environmentally-friendly consumer products. British Journal of Management, 7(3), 263 - 281. 